\title{
Spatial-Temporal Business Partnership Selection in Uncertain Environments
}

University of Minho, Dep. of Production and Systems, 4800-058 Guimarães Portugal

Maria Leonilde R. Varela

University of Minho, Dep. of Production and Systems, 4800-058 Guimarães Portugal

Rita A. Ribeiro UNINOVA - CA3, 2829-516 Caparica Portugal

Goran D. Putnik

University of Minho, Dep. of Production and Systems, 4800-058 Guimarães

Portugal
Small and Medium (SME) companies are facing growing challenges while trying to implement globalized business strategies. Contemporary business models need to account for spatial-temporal changeable environments, where lack of confidence and uncertainty in data are a reality. Further, SMEs are finding it increasingly difficult to include all required competences in their internal structures; therefore, they need to rely on reliable business and supplier partnerships to be successful. In this paper we discuss a spatial-temporal decision approach capable of handling lack of confidence and imprecision on current and/or forecast data. An illustrative case study of business' partner selection demonstrates the approach suitability, which is complemented by a statistical analysis with different levels of uncertainty to assess its robustness in uncertain environments.

Keywords Spatial-temporal multi-criteria decision making, data uncertainty filtering, business partnerships, data fusion

\section{INTRODUCTION}

When a company decides to extend its competences by establishing business partnerships, it needs decision support tools and methods to select the best partners or suppliers, particularly in today's spatial-temporal changeable global environments and several interesting contributions have been put forward during the last years $[1,2,3]$. Businesses need a suitable evaluation approach capable of supporting spatial-temporal selection processes within uncertain environments.

Hence, in this paper we discuss how to tackle spatial-temporal decision making in uncertain environments. The followed approach combines concepts from a general data fusion method capable of handling imprecision on data [4] with a spatial-temporal multi-criteria model [5], which integrates historical information, present status and forecasting about future information. Further we propose to use a simple fuzzification process to normalize the data [6]. The final objective is to allow companies to rank business partners, using customizable criteria (which may change over time), as well as it may include some form of imprecision (derived from uncertain contexts) such as lack of confidence and/or deviations from nominal values. After computing a possible decision for each temporal process (past, present and future data), the three evaluations are fused to obtain a ranked list of partners and/or suppliers. This will result on more informed and robust decisions to be taken, based on the procurement management strategy the buyer company finds appropriate. Furthermore, since it is a spatialtemporal approach, it enables SME's to change their

Received: October 2015, Accepted: November 2015

Correspondence to: Dr Leonilde Varela

University of Minho,

Campus of Azurem, 4800-058 Guimaraes, Portugal

E-mail: Leonilde@dps.uminho.pt

doi:10.5937/fmet1504353A

(C) Faculty of Mechanical Engineering, Belgrade. All rights reserved strategic decisions periodically, without losing either past information or acquired knowledge about future trends.

To clarify the approach we use a small case study of business partner selection with five suppliers and three sets of criteria for data evaluation. Afterwards, to demonstrate the flexibility and robustness of the method, we perform a statistical analysis over 30 similar problems - with data from past, future and present information - which are tested within three uncertain contexts: low confidence, average and high confidence on data.

The paper is organized as follows. In section 2 we provide the background for the dynamic approach. In section 3 we present the steps of the combined approach for business partnership evaluation. In section 4 we use a small illustrative example to show how the approach is applied and then we perform a statistical analysis to demonstrate the approach robustness and versatility. In section 5 we briefly discuss the results of this work.

\section{BACKGROUND ON SPATIAL-TEMPORAL DECISION MODEL}

Classical multi-criteria decision making MCDM models assume that criteria ratings and weights are known a priori and they are precise. It is then reduced to a static single decision matrix that reflects the system status $[7,8]$, as follows (Figure 1). Where $x_{i j} \in[0,1]$ represents the level of achievement of an alternative $i$ with respect to criterion $\mathrm{j}$ and the relative importance of criteria can be encoded by means of a weight vector.

In the classic MCDM model, the decision maker fixes sets of alternatives and criteria at the beginning. Then, each alternative is evaluated with respect to each criterion and these values are transformed, by means of an aggregation function, into a final rating value. With the final scores, alternatives can be easily ranked and the best one(s) is selected. It is a static process that does 
not take into consideration neither spatial nor temporal events (e.g. changeable criteria, new alternatives or new criteria, disappearance of alternatives etc).

$$
\begin{aligned}
& \begin{array}{cccc}
C_{1} & C_{2} & \ldots & C_{n}
\end{array} \\
& \begin{array}{l}
a_{1} \\
a_{2}
\end{array} \quad\left[\begin{array}{llll}
x_{11} & x_{12} & \ldots & x_{1 n} \\
x_{21} & x_{22} & \ldots & x_{2 n} \\
a_{3} & x_{32} & \ldots & x_{3 n}
\end{array}\right]=\left[\begin{array}{l}
A_{1} \\
A_{2}
\end{array}\right. \\
& a_{3} \quad \begin{array}{llll}
x_{31} & x_{32} & \ldots & x_{3 n}
\end{array}==\begin{array}{l}
A_{2} \\
A_{3}
\end{array} \\
& a_{\mathrm{m}} \quad\left[\begin{array}{cccc}
x_{31} & x_{32} & \ldots & x_{3 n} \\
\ldots & \ldots & \ldots & \ldots \\
x_{m 1} & x_{m 2} & \ldots & x_{m n}
\end{array}\right]\left[\begin{array}{c}
A_{3} \\
A_{m}
\end{array}\right]
\end{aligned}
$$

\section{Figure 1: Static decision matrix used in classical MCDM}

This classic single decision matrix limits the decision relevance because it ignores information from the past-which may provide valuable inputs about how a supplier behaved, as well as any future estimated information (e.g. knowledge about new investments or new processes that will improve supplier's performance). To better support this type of decisions we need to move from static MCDM models to dynamic ones, where spatial-temporal considerations are taken in consideration by using multiple matrices during the evaluation process [5]. Dynamic Multi Criteria Decision Making is an emerging research subject that considers changeable inputs and temporal considerations as important variables to be taken into account in any dynamic decision process [9-14]. Further, the number of alternatives and criteria may vary with time, period or interaction. For each time period the decision matrix is combined with the previous one in a feedback loop, thus providing the dynamicity for the model. Jassbi, Ribeiro and Varela (2014) [5] extended this model with future information for supplier selection. They added a prognostic matrix, representing criteria estimated values for the same alternatives as the historical decision matrices. Past, present and future matrices were then merged, using a simple weighted average, to rate and rank suppliers at each evaluation period. However, that approach [5] did not take in consideration data fusion issues, such as: normalization/fuzzification; weights depending on satisfaction level in criteria; uncertainty both in the data confidence and interval imprecision (accuracy); and also aggregation operators capable of penalizing or rewarding satisfaction levels of alternatives for the three time phases (past, present and future). Our main objective here is to discuss a complementary approach capable of tackling uncertainty issues, in spatial-temporal decision contexts, as discussed in the next section.

\subsection{Uncertainty contexts in decision making}

Merging past information with present information and also future trends (or forecasts) may improve the quality of the decision making process, but it is not a risk free process. Adding more information may imply adding more uncertainty to the evaluation process [15] such as: (1) Imprecision associated with the difficulty of scoring alternatives on criteria - due to the absence of relevant information or the inability of a decision maker to express his preferences in a consistent way; (2) Stochastic uncertainty and (3) Indetermination - associated to criteria definition and its interpretation. Moreover, according to [16], imprecision can arise from a variety of sources: incomplete knowledge, inexact language, ambiguous definitions, and measurement problems, among others. Models for supplier selection frequently lack support for dealing with imprecision, assuming that precise data and preferences are available [17]. This oversimplification may lead to erroneous decisions, particularly in today's evolving and fast changing global markets environments. On the other hand, as mentioned above, when more evaluation parameters are used, along with extended data sets, we may be introducing more imprecision in the decision process, even if criteria is clearly defined and imprecision is avoided. Imprecision may be intrinsic due to the nature of the selected evaluation parameters, such as estimations and/or subjective supplier evaluation parameters, and also due to imprecise human reasoning.

Fuzzy logic [18] has been successfully used for handling imprecision in decision making processes, particularly in Multiple Criteria Decision Making models (among others: [19-24]). In this work we assume there is some sort of uncertainty in the data available, therefore, fuzzy logic concepts will be used to normalize the criteria - thus enabling numerical and comparable data to be aggregated - and then an uncertainty filtering mechanism will be used to tackle the lack of confidence and existing interval deviations on past, current and future data. Specifically, we will use a complete data fusion process, proposed by Ribeiro et al., in 2013 [4], denoted FIF - a fuzzy information fusion algorithm. The authors propose a Data Fusion process, based on fuzzy multi-criteria decision making concepts and techniques, such as: fuzzy sets to normalize the variables; an uncertainty mechanism to handle data imprecision; and mixture operators with weighting functions to fuse the information into a composite of candidate alternatives. The model is particularly suitable for handling dynamic decision problems in uncertain contexts. Further, the criteria weights include parameters that may be fine-tuned, to control the relative importance of criteria when fusing the information. Pais et al., in 2010 [14] have successfully applied the model to a spacecraft landing on planets scenario where hazard maps (e.g. "low slope") are the criterion and the candidate alternatives are the target sites (pixels). After the fuzzy normalization, the individual maps (criteria) are fused, generating a composite map, with the aggregated score for each alternative, being each pixel a candidate alternative.

FIF [4] was not created to support selecting alternatives, but only to fuse information and to tackle data imprecision. Therefore, it does not include temporal considerations, which means that decisions will neither take into account historical trends nor future evolutions. Since here the focus is on how to handle spatial-temporal models with future information within uncertain contexts, our approach combines the FIF method [4] with a dynamic decision model, which integrates historical, current and forecasting information, to support business/supplier selection [5]. 


\section{SPATIAL-TEMPORAL PARTNER/SUPPLIER SELECTION IN UNCERTAIN CONTEXTS}

\subsection{Evaluation Criteria}

A set of criteria must be selected to allow each alternative to be evaluated and rated with the aim to chose the best business partners for a given business scenario. Examples of current criteria to evaluate suppliers can be Price or Delivery time, among others. For historical information one may use on time delivery performance or any other criteria. Criteria must be selected according to the scenario requirements and the availability of information about the business/suppliers, as for example [25]: amount of damage, number of credit claims, number of customer returns and cost of returned goods.

\subsection{Create Past, Present and Future Evaluation Matrices}

The past matrix should be built using historical information regarding the supplier's performance. Past criteria satisfaction values may be obtained from information stored in a database about suppliers past behaviour. When analysing information about the past, parameters such as price, delivery time and lead time may be considered, but more importantly is to consider historical data on time delivery performance and defect delivery rates.

When evaluating the present status, data included in the received quotes/proposals is of utmost importance. Proposals/quotes may include price, lead and delivery times, and other specific data. This information may be aggregated with quality and delivery performance rates, thus allowing taking risks into account in the decision making process. Finally, to build the future evaluation matrix, some forecasting must be defined. The forecast may target criteria such as performance indexes and prices, basing the assumptions about future values on past performance patterns.

$$
\begin{aligned}
& \text { Past Present }
\end{aligned}
$$

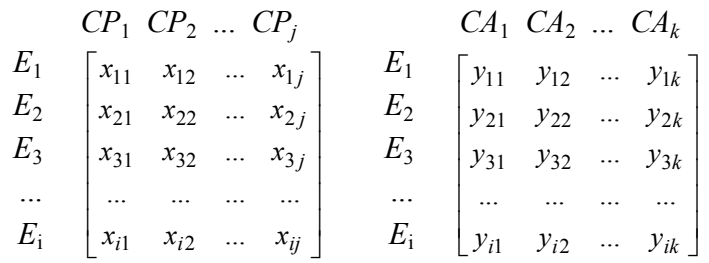

$$
\begin{aligned}
& \text { Future } \\
& \begin{array}{llllllllllllllll}
C P_{1} & C P_{2} & \ldots & C P_{n}
\end{array} \\
& \begin{array}{c}
E_{1} \\
E_{2} \\
E_{3} \\
\ldots \\
E_{\mathrm{i}}
\end{array} \quad\left[\begin{array}{cccc}
z_{11} & z_{12} & \ldots & z_{1 n} \\
z_{21} & z_{22} & \ldots & z_{2 n} \\
z_{31} & z_{32} & \ldots & z_{3 n} \\
\ldots & \ldots & \ldots & \ldots \\
z_{i 1} & z_{i 2} & \ldots & z_{i n}
\end{array}\right]
\end{aligned}
$$

Figure 2: The three matrices for spatial-temporal decisionmaking.
Figure 2 formalizes the three decision matrices, where different criteria (spatial characteristic) can be considered to evaluate past, present and future performance (temporal aspect). It should be noticed that the dynamic model [13] used in this work also allows new alternatives (e.g. suppliers) to be added, and/or removal of existing suppliers in either one of the 3 matrices, but for simplicity in Figure 2 they are the same.

\subsection{Criterion Normalization process (fuzzification)}

When dealing with diverse domains and also qualitative or quantitative criteria we need to ensure comparability to process the data, i.e. all criteria must be normalized before any fusion process occurs [4]. Normalization is essential to guarantee that criteria values (also called levels of attainment or satisfaction) are numerical and comparable to enable their mathematical aggregation. Just dividing a criterion level of satisfaction by its maximum value on the set (when high values are good, such as quality index) or by its minimum (when low values are good, such as price) is a fast way to normalize the respective decision matrix entries. However, that simple method does not allow expressing semantic evaluations or criteria levels of attainment; i.e. they lack both a semantic interpretation to properly express concepts such as "lower is better" as well as intelligent comparative evaluation of scores for each alternative regarding criteria. One way to answer that requirement is to use fuzzification as a normalizing procedure, because, fuzzy memberships provide a 2tuple with the criteria (variable) value plus its respective pertaining level (details about fuzzification methods can be seen in [26]). Further, and due to its versatility, we propose using triangular membership functions for fuzzification/normalization, thus providing a semantic interpretation for criteria such as "lower is better" and "higher is better", as depicted in equation 1 and illustrated in Figure 3 [6].

Lower is better:

$$
\mu(x)=\left\{\begin{aligned}
0, & \text { if } x>b_{i}+p_{i} \\
1-\frac{x-b_{i}}{p_{i},} & \text { if } b_{i}<x \leq b_{i}+p_{i} \\
1, & \text { if } x \leq b_{i}
\end{aligned}\right.
$$

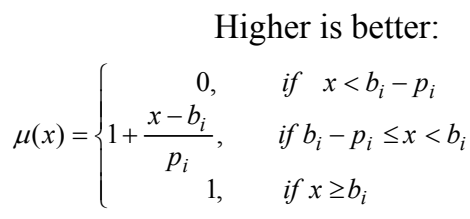
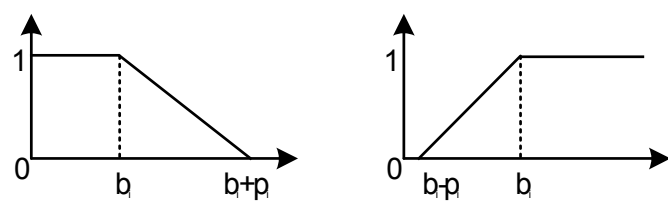

Figure 3: Illustration of normalizing functions for "lower is better" and "higher is better".

It should be noted that the proposed membership functions (eq. 1) could be adjusted for any other context 
and could also represent equalities, such as "equal to" when the triangle is closed in the left and right [6]. After the normalization process (i.e. fuzzification when fuzzy memberships are used) we obtain three normalized matrices, where the cell's values (Figure 2) are substituted by the respective membership value, $\mu(\mathrm{x})$ from (eq. 1); here also called the level of achievement or attainment.

Summarizing, the proposed normalization process provides a semantic interpretation of the original score of the attribute, where high membership signifies that a criterion is well satisfied and vice versa for low satisfaction, as well as it ensures all criteria are judged on the same scale - essential to enable aggregating diverse domains' criteria.

\subsection{Filtering uncertainty}

All information gathered about the criteria level of achievement may have embedded uncertainty due to: lack of precision while gathering data; subjective information or evaluation; or even lack of confidence in the quality of the gathered data for specific criteria. In order ensure tackling this sort of imprecision we will use the method proposed in [4], which includes two imprecision metrics to deal with lack of accuracy and/or confidence. The first parameter expresses deviations from nominal values and the second expresses the degree of trust on the quality of data gathered. The logic of this filtering process is that if we do not trust an input source (e.g. confidence on data is only $80 \%$ ) then the initial value must decrease proportionally (e.g. a value 10 would be reduced to 8 ). The accuracy metric allows considering deviations, as for example +3 or -3 from a nominal value of 10 .

Formally, let $\mathrm{a}_{\mathrm{ij}}$ be an inaccuracy value associated with criterion $\mathrm{j}$ for supplier $\mathrm{i}$, representing a left or right deviation from the original value. When $a_{i j}$ is zero it means we accept the gathered value without deviation errors. The confidence, $w_{\mathrm{j}}$, is a percentage of the trust in the collected data. For example, we trust with $90 \%$ the values collected for criterion "On Time Delivery Performance". Additionally, $\lambda[0,1]$ reflects the decision maker's attitude: lower values indicate an optimistic attitude; higher values indicate a pessimist attitude. The adjusted membership value, $\mathrm{u}_{\mathrm{ij}}$, for criterion $\mathrm{j}$ of supplier $i$, is then calculated using the following formula [4]:

$u_{i j}=w c_{j}^{*}\left(1-\lambda * \max _{x \in[a, b]}\left\{\left|\mu(x)-\mu\left(x_{i j}\right)\right|\right\}\right) * \mu\left(x_{i j}\right)$

where $[a, b]$ is the domain interval of any criterion, such that:

$$
\begin{aligned}
& a= \begin{cases}\min (D), & \text { if } x_{i j}-a_{i j}<\min (D) \\
x_{i j}-a_{i j}, & \text { if } x_{i j}-a_{i j} \geq \min (D)\end{cases} \\
& b= \begin{cases}x_{i j}+a_{i j}, & \text { if } x_{i j}+a_{i j} \leq \max (D) \\
\max (D), & \text { if } x_{i j}+a_{i j}>\max (D)\end{cases}
\end{aligned}
$$

Using this filtering uncertainty function we are able to penalize imprecise input values, which display any of the two types of uncertainty, i.e. inaccuracies and/or lack of confidence.

In Figure 4 we illustrate this filtering uncertainty process. Let's assume we have five different suppliers being evaluated. Each supplier has an associated cost per hour $(\mathrm{CPH})$, based on existing information about past orders. Decision makers have only $75 \%$ confidence $\left(\mathrm{wc}_{\mathrm{j}}\right)$ on this data, because the increased competition has recently pushed some suppliers to issue quotes with lowered prices, meaning that the new quoted values may not follow the trend of past quotes. They also assume a pessimist attitude $(\lambda=1)$, although they consider that values precisely reflect historical behaviour $\left(\mathrm{a}_{\mathrm{ji}}=0\right)$. Based on each criterion value $\left(\mathrm{x}_{\mathrm{ij}}\right)$, we calculate the associated membership function $\left(\mu\left(x_{i j}\right)\right)$, using equation 1 . Next, we filter the values, using the defined $w_{j}, a_{i j}$ and $\lambda$ values.

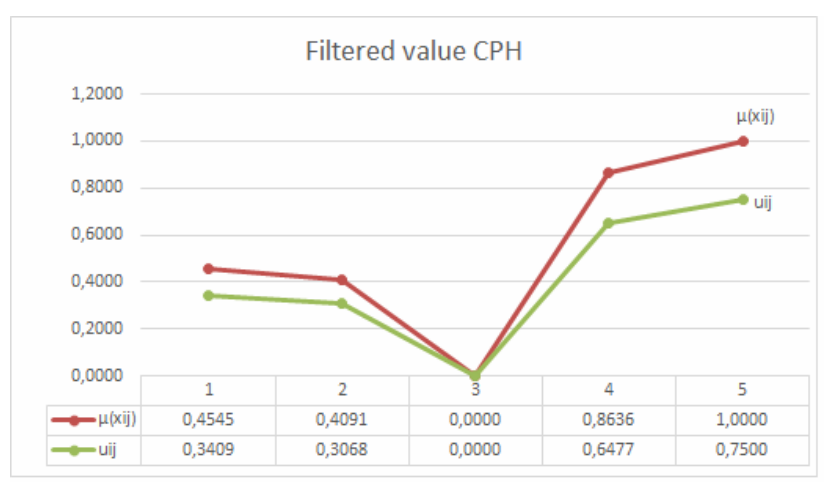

Figure 4: Illustration of filtering uncertainty in cost-perhour with 5 scores.

Observing Figure 4 it is obvious that when in presence of uncertainty the levels of satisfaction (membership values) are reduced by using filtering, as shown in the $u_{i j}$ function plot. An increased level of uncertainty will produced lower values, thus minimizing its impact on the final evaluation process.

\subsection{Relative importance of criteria with weighting functions}

Following the work of [4], we now need to define the weighting functions that will represent the relative importance of each criterion. Here we use linear weighting functions due to its simplicity and flexibility, and they are formalized in equation 3 . These weighting functions allow penalizing or rewarding bad or good levels of criteria satisfaction, i.e. instead of assigning single weights, a weighting function depending on criteria satisfaction is used [27, 28].

$$
L\left(u_{i j}\right)=\alpha * \frac{1+\beta u_{i j}}{1+\beta}, 0 \leq \alpha, \beta \leq 1
$$

where $\alpha$ defines the semantic importance of criteria, and $\beta$ defines the respective slopes for the respective weighting functions (a higher value means a steeper function). 
Figure 5 depicts an example for three weighting functions: very important-VI $(\alpha=1 ; \beta=0.67)$, importantIMP $(\alpha=0.8 ; \beta=0.67)$ and average-W $(\alpha=0.8 ; \beta=1)$.

For instance, in Figure 5 it can be observed how a filtered membership value $u_{i j}$ of 0.5 (attainment level of criterion) will be assigned a weight of 0.8 when the criterion is "very-important", however, if the attainment level (filtered value) is 0.8 then its relative weight will increase to 0.92 .

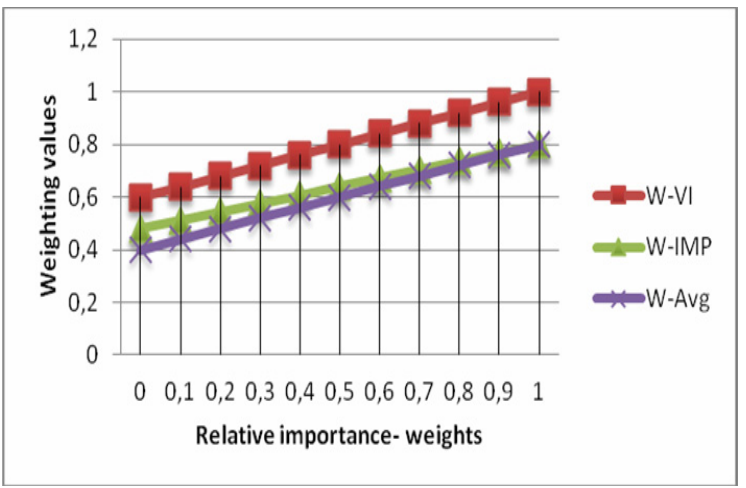

Figure 5: Illustrative example for three weighting functions.

In summary, the proposed weighting functions are used to penalize or reward relative weights, either by reducing the weight of badly satisfied criteria and to reward high performance. Next we explain how these relative weights are combined with the filtered values to obtain the final score for each alternative.

\subsection{Intra-Aggregation (Spatial)}

At this stage we already have the three matrices with their respective rated cells values $\left(\mathrm{u}_{\mathrm{ij}}\right)$, for each existing criterion, per alternative supplier, for the three temporal periods (past, present and future). The obtained rates are the result of normalization, filtering uncertainty and weighting with weight functions. Considering we may have different criteria for each time period, we start by an intra aggregation (spatial) to obtain the resulting vectors for past, present and future ratings, per supplier. After, we perform the temporal inter-aggregation, as described in section 3.7.

As mentioned, the aggregation method used [4] is based on the mixture of operators with weighting functions [27] as follows,

$$
r_{i}=\operatorname{sum}_{i}\left(\frac{L\left(u_{i j}\right) * u_{i j}}{\sum_{j=1}^{n} L\left(u_{i j}\right)}\right)
$$

where $u_{i j}$ is the filtered normalized value for criteria $j$ and supplier $\mathrm{i}$, and $\mathrm{L}\left(\mathrm{u}_{\mathrm{ij}}\right)$ is the corresponding weighted value, calculated with a linear weighting function, equation 3 .

Notice that this aggregation method belongs to the averaging family and it is an extension of the simple weighted average. After executing this step for the three time periods we obtain the ratings for past, present and future information per supplier.

\subsection{Inter aggregation (Temporal): final rating}

After obtaining the scoring vectors for the three types of matrices (past, present and future) we are now able to use the dynamic spatial-temporal process [5, 13] for obtaining the final rating for all alternatives.

To perform the inter-aggregation, i.e. temporal aggregation, we can use operators such as weighted average, mixture operators with weighting functions (our choice) or any other operator. For example, if we use a simple weighted average we may consider that past information is more relevant than future one and assign more weight to this temporal-criterion than to the future one. Again, any other operator from average, geometric mean, or even parametric operators could be used for determining the final evaluation for each supplier.

In summary, the vectors are combined and the result is a single score per supplier, which after being ordered displays the ranking of all suppliers. With our approach the ranking vector provides more informed information for the buyer to select the best suppliers or business partners, since it reflects their past, current and future expected behaviours. Obviously, the final ratings are greatly influenced by the chosen criteria and respective evaluations and parameters chosen. The buyer company may adjust these parameters, according to the specificities of its business scenario.

\section{NUMERICAL EXAMPLE OF BUSINESS PARTNER SELECTION}

\subsection{Problem description}

For applying our proposed approach we use a business partner/supplier selection illustrative example. Let us consider the proposals and quotes sent by five candidate suppliers ( $\mathrm{Si}$ ) evaluated using the following criteria: quoted price (QP); Total Delivery Time (TDT) (corresponding to the sum of the quoted Delivery Time and Lead Time); Current Portfolio Rating (CPR), which refers to the quality of the company's portfolio of customers and projects; and Company Maturity Index (CMI). CMI is calculated using a weighted sum of the company size evaluation (40\%), financial health assessment (45\%) and an activity rating based on the number of years of business activity $(30 \%)$.

Historical information is gathered for the set of four criteria used for evaluating past information: Cost Per Hour (CPH); On time Delivery Performance (ODP); Quality Performance (QLP), based on the rate of defect free past deliveries; and Value of Claims (VOC). VOC is calculated using a weighted sum of the existing Number of Claims (NOC) that were put in the past to the corresponding supplier or business $(30 \%)$ and the Cost of Claims (COC), which expresses the costs associated with the past claims (70\%).

In the future matrix the criteria are: Estimated Cost Per Hour (ECPH), based on past price performance; Estimated Delivery Performance (EDP); Estimated Quality Performance (EQP); and Estimated Strategic Rating (ESR), based on how important a given business is according to its business potential. The estimates are 
based on past performance patterns, reflecting associated trends. Figure 6 summarizes the criteria input data used to rank the 5 suppliers.

$$
\text { Present: Past: Future: }
$$
CPH ODP QLP VOC QP TDT CPR CMI ECPH EDP EQP ESR $\mathrm{S}_{1}\left[\begin{array}{llll}75 & 80 \% & 80 \% & 10501\end{array}\right] \mathrm{S}_{1}\left[\begin{array}{llll}25500 & 55 & 100 \% & 36.37\end{array}\right] \mathrm{S}_{1}\left[\begin{array}{lllll}75 & 85 \% & 75 \% & 1\end{array}\right]$ \begin{tabular}{c|cccc|c|cccc|c|cccc}
$\mathrm{S}_{2}$ & 80 & $95 \%$ & $90 \%$ & 0 & $\mathrm{~S}_{2}$ & 30000 & 55 & $98 \%$ & 109.63 & $\mathrm{~S}_{2}$ & 90 & $95 \%$ & $90 \%$ & 7
\end{tabular} \begin{tabular}{l|cccc|c|cccc|ccccc}
$\mathrm{S}_{3}$ & 125 & $90 \%$ & $98 \%$ & 3501 & $\mathrm{~S}_{3}$ & 56000 & 45 & $98 \%$ & 100.75 & $\mathrm{~S}_{3}$ & 180 & $99 \%$ & $95 \%$ & 6 \\
\hline & 30 & $75 \%$ & $70 \%$ & 5250 & $\mathrm{~S}_{4}$ & 12500 & 80 & $95 \%$ & 22.76 & $\mathrm{~S}_{4}$ & 35 & $65 \%$ & $72 \%$ & 3
\end{tabular}

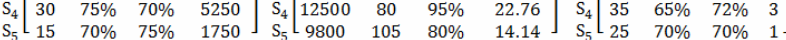

Figure 6: Past, present and future input data about candidate suppliers (xij).

Next, we perform the criterion normalization process. For each criterion $\mathrm{j}$, the corresponding membership value uij is calculated for each supplier $\mathrm{i}$, using the normalizing function (equation 1). We applied "lower is better" for criteria CPH, VOC, QP, TDT, ECPH and "higher is better" for ODP, QLP, CPR, CMI, EDP, EQP, ESR. The normalized (fuzzified) results are shown on Figure 7:

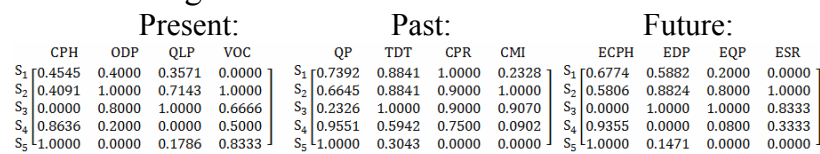

Figure 7: Normalization results for each supplier and defined criteria $\left(\mu\left(x_{i j}\right)\right)$.

After the normalization process we proceed with tackling the data uncertainty by using the filtering equation 2. For each criterion $\mathrm{j}$ and supplier $\mathrm{i}$, an inaccuracy level is defined $\left(\mathrm{a}_{\mathrm{ij}}\right)$, representing the assumed deviation from the effective value. Additionally, we estimate the confidence wij, representing the percentage of trust in each criterion. Finally, we consider if the attitude from the decision maker is either optimistic or pessimist $(\lambda)$.

For example, criterion Current Portfolio Rating is based on a subjective evaluation of the candidate product and project portfolio, performed by different employees. As such, the decision maker has a relatively low confidence on the criterion evaluations $\left(\mathrm{w}_{\mathrm{j}}=60 \%\right)$. Additionally, since different employees are performing the analysis, the accuracy of the values provided is limited $\left(\mathrm{a}_{\mathrm{ij}}=5 \%\right)$. Therefore, using equation 2 , we will have the values for criterion Current Portfolio rating (CPR) as illustrated on Table 1:

Table 1. Illustration for CPR in current information.

\begin{tabular}{ccccll}
\multicolumn{7}{c}{ CPR (Current Portfolio Rating) } \\
Supplier & Rating & Normalized & Filtered & & \\
j & $\left(x_{i j}\right)$ & $\mu\left(x_{i j}\right)$ & $\left(u_{i j}\right)$ & & \\
S1 & $100 \%$ & 1.000 & 0.600 & $\mathrm{wc}_{\mathrm{j}}:$ & $60 \%$ \\
S2 & $98 \%$ & 0.900 & 0.486 & $\lambda:$ & 1 \\
S3 & $98 \%$ & 0.900 & 0.486 & $\mathrm{ac}_{\mathrm{j}}:$ & $5 \%$ \\
S4 & $95 \%$ & 0.750 & 0.338 & & \\
S5 & $80 \%$ & 0.000 & 0.000 & &
\end{tabular}

The same process is applied for all remaining criteria. Figure 8 illustrates the uncertainty filtering results for past, present and future criteria $\left(\mathrm{u}_{\mathrm{ij}}\right)$.

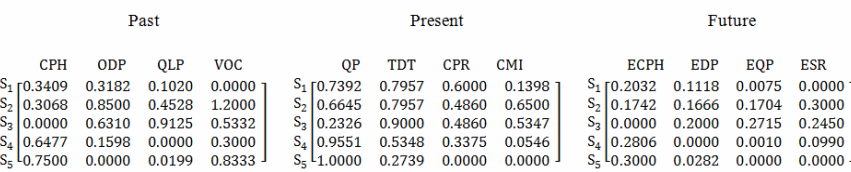

Figure 8: Filtered data for past, present and future criteria
Next, we use weighting functions to perform the data fusion process [4] following equation 4. First, the respective relative importance (weighting functions) are defined using the parameters shown in Figure 9. Notice the linear functions are similar to the ones illustrated in Figure 5 but the three relative importance weighting functions parameters were: $\alpha$ (very important: 1; important: 0.8; average importance: 0.6); and the slope control parameter $\beta$ (High slope decrease: 1; Medium slope decrease: 0.67$)$.

\begin{tabular}{|c|c|c|c|c|c|c|c|c|c|c|c|}
\hline \multicolumn{4}{|c|}{ Past } & \multicolumn{4}{|c|}{ Present } & \multicolumn{4}{|c|}{ Future } \\
\hline CPH & ODP & QLP & VOC & QP & TDT & CPR & CMI & ECPH & EDP & EQP & ESR \\
\hline 1 & 0,8 & 0,8 & $0,8]$ & $\alpha[1$ & 0,8 & 0,6 & 0,5 & ${ }^{\alpha}\left[\begin{array}{c}1 \\
\beta\end{array}\right.$ & 0,8 & 0,8 & $0,6]$ \\
\hline$\left.\beta\right|_{0,67}$ & 0,67 & 0,67 & $1]$ & $\beta[1$ & 0,67 & 0,67 & 0,67 & $\beta\lfloor 0,67$ & 0,67 & 0,67 & 0,67 \\
\hline
\end{tabular}

Figure 9: Weighting functions 'parameters used for existing criteria.

Weighted values, $\mathrm{L}\left(\mathrm{u}_{\mathrm{ij}}\right)$, are then obtained using the filtered and normalized values $\mathrm{u}_{\mathrm{ij}}$ (Figure 7) using equation 3. After calculating the filtered normalized values (Figure 8) along with their corresponding weighted values, we use equation 4 to perform the spatial intra-aggregation.

Ratings using relative importance $\mathrm{L}\left(\mathrm{u}_{\mathrm{ij}}\right)$ multiplied by filtered value:

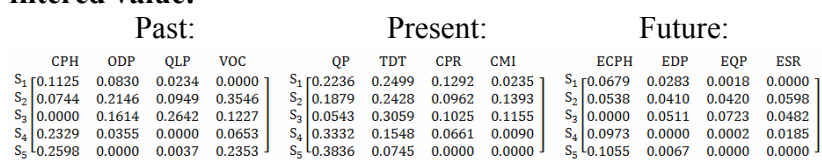

After spatial intra-aggregation (using equation 4):

\begin{tabular}{|c|c|c|}
\hline$r_{i}$ & $r_{i}$ & $r_{i}$ \\
\hline $\mathrm{S}_{1}[0.2190$ & $\mathrm{S}_{1}[0.6262]$ & $\mathrm{S}_{1}[0.0979]$ \\
\hline \begin{tabular}{l|l|l}
$\mathrm{S}_{2}$ & 0.73885
\end{tabular} & \begin{tabular}{l|l}
$\mathrm{S}_{2}$ & 0.6661
\end{tabular} & \begin{tabular}{l|l}
$\mathrm{S}_{2}$ & 0.1965
\end{tabular} \\
\hline \begin{tabular}{l|l}
$\mathrm{S}_{3}$ & 0.5483
\end{tabular} & \begin{tabular}{l|l}
$\mathrm{S}_{3}$ & 0.5781
\end{tabular} & \begin{tabular}{l|l}
$\mathrm{S}_{3}$ & 0.1716
\end{tabular} \\
\hline \begin{tabular}{l|l}
$\mathrm{S}_{4}$ & 0.3337
\end{tabular} & \begin{tabular}{l|l}
$\mathrm{S}_{4}$ & 0.5632
\end{tabular} & \begin{tabular}{l|l}
$\mathrm{S}_{4}$ & 0.1160
\end{tabular} \\
\hline${ }_{5} \mathrm{~L}_{0.4988}$ & $\mathrm{~S}_{5} \mathrm{~L}_{0.4581}$ & $\mathrm{~S}_{5} \mathrm{~L}_{0.1122}$ \\
\hline
\end{tabular}

Figure 10: Relative weights and corresponding intraaggregation (spatial).

To illustrate how calculations for the intraaggregation ratings (equation 4) were made let us see Supplier ("S2") and criteria CPH of past information: a) first we obtain the score for criteria $\mathrm{CPH}$ as follows: where, $\mathrm{r}(\mathrm{CPH}): 0.7219 / 2.9781 * 0.3068=0.0744$,

$\operatorname{SUM}\left(L\left(\mathrm{u}_{\mathrm{ij}}\right)\right)=0.7219+0.7519+0.6244+0.88=2.9781$

$\mathrm{u}_{\mathrm{ij}}=0.3068 . \mathrm{L}\left(\mathrm{u}_{\mathrm{ij}}\right)=0.7219$

b) then we calculate the rating for "S2" for past information (left vector) by aggregating all criteria with a simple sum (because we already weighted the elements in the previous step), as follows:

$\mathrm{r}(\mathrm{S} 2)=0.0744+0.2146+0.0949+0.3546=0.7385$

After obtaining the ratings for each matrix, past, present and future, the dynamic spatial-temporal process provides the final rating for all candidate businesses/suppliers, as depicted in Figure 11 (final score).

Illustrating again for Supplier 2 (S2), we determined the final score (Figure 11) using again equation 4, as follows:

a) sum of relative weights for $\mathrm{S} 2, \operatorname{SUM}\left(\mathrm{L}\left(\mathrm{u}_{\mathrm{ij}}\right)\right)=$ $0.7161+0.833+0.4066=1.9557$ 
b) Rating of inter-aggregation (Temporal) for S2, $\mathrm{r}(\mathrm{S} 2)=(0.7161 / 1.9557) * 0.7385+(0.833 / 1.9557)$ $* 0.6661+(0.4066 / 1.9557) * 0.1965=0.595$ (final score)

\begin{tabular}{|c|c|}
\hline \multicolumn{2}{|c|}{ Past Weighted } \\
\hline $\mathrm{S}_{1}[0.2190$ & $0.5493]$ \\
\hline \begin{tabular}{l|l}
$\mathrm{S}_{2}$ & 0.7385
\end{tabular} & 0.7161 \\
\hline \begin{tabular}{l|l}
$\mathrm{S}_{3}$ & 0.5483
\end{tabular} & 0.6550 \\
\hline \begin{tabular}{l|l}
$\mathrm{S}_{4}$ & 0.3337
\end{tabular} & 0.5862 \\
\hline $\mathrm{S}_{5} \mathrm{~L}_{0.4988}$ & 0.6391 \\
\hline
\end{tabular}

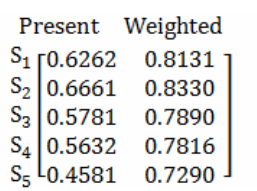
Future Weighted $\mathrm{S}_{1}\left[\begin{array}{ll}0.0979 & 0.3829\end{array}\right]$ $\mathrm{S}_{2} \quad 0.1965 \quad 0.4066$ \begin{tabular}{l|ll}
$\mathrm{S}_{3}$ & 0.1716 & 0.4006
\end{tabular} $\mathrm{S}_{4}\left[\begin{array}{lll}0.1160 & 0.3872\end{array}\right.$ $\mathrm{S}_{5} \mathrm{~L}_{0.1122} 0.3863$

\begin{tabular}{|c|c|c|c|}
\hline \multirow{3}{*}{\multicolumn{2}{|c|}{$\begin{array}{c}\text { Pa. Pr } \\
\alpha \\
\beta\left[\begin{array}{c}0,8 \\
0,67\end{array}\right.\end{array}$}} & Fut. & Final Rating \\
\hline & & $0,6]$ & $\mathrm{S}_{1}[0.3821]$ \\
\hline & & $0,67]$ & \begin{tabular}{l|l}
$\mathrm{S}_{2}$ & 0.5950
\end{tabular} \\
\hline & & & \begin{tabular}{l|l|l}
$\mathrm{S}_{3}$ & 0.4792
\end{tabular} \\
\hline & & & \begin{tabular}{l|l}
$\mathrm{S}_{4}$ & 0.3879
\end{tabular} \\
\hline & & & $\mathrm{S}_{5} \mathrm{~L}_{0.3967}$ \\
\hline
\end{tabular}

Figure 11: Final vector ratings and final score

Finally, we are now able to conclude that Supplier 2 (S2) should be selected for accomplishing the service as it is the top ranked candidate business, with a final score of 0.595 .

\subsection{Statistical analysis}

In this section we perform a statistical analysis to demonstrate the robustness of the proposed approach for supporting businesses selection. This statistical analysis is performed over thirty similar problems (simulated) with data from past, future and present information, for the same set of five businesses or suppliers.

Three different sensitivity analysis scenarios were applied (Tables 2, 3 and 4) regarding filtering uncertainty, by using low, average and high confidence ratings, for the spatial-temporal data to be fused $[4,5]$. The three scenarios were applied to thirty similar simulated problems as explained below and resumed in Tables 5 to 7 .

\subsubsection{Scenarios description}

\section{Scenario 1 (C1): "Low-confidence rating"}

The first scenario (Scenario 1, or Sc1 for short) is a low-confidence rating scenario, which reflects lack of confidence on criteria information regarding past, future and present, as expressed on Table 2.

Table 2. Past, present and future information about scenario 1.

\begin{tabular}{|l|c|c|c|c|c|c|c|c|c|c|c|c|}
\hline & \multicolumn{4}{|c|}{ Past } & \multicolumn{5}{c|}{ Present } & \multicolumn{3}{c|}{ Future } \\
\cline { 2 - 11 } Criterion (j) & CPH & ODP & QLP & VOC & QP & TDT & CPR & CMI & ECPH & EDP & EQP & ESR \\
\hline Confidence & $75 \%$ & $85 \%$ & $50 \%$ & $60 \%$ & $90 \%$ & $90 \%$ & $60 \%$ & $70 \%$ & $90 \%$ & $90 \%$ & $90 \%$ & $60 \%$ \\
\hline
\end{tabular}

\section{Scenario 2 (C2): “Average-confidence rating"}

The second scenario considered (Scenario 2, or Sc2 for short) is an average-confidence rating scenario, as it uses average percentages for reflecting the confidence about the information regarding past, future and present data, as expressed in Table 3:

Table 3. Average confidence levels for past, present and future information.

\begin{tabular}{|l|c|c|c|c|c|c|c|c|c|c|c|c|}
\hline & \multicolumn{4}{|c|}{ Past } & \multicolumn{4}{c|}{ Present } & \multicolumn{4}{c|}{ Future } \\
\cline { 2 - 12 } & CPriterion (j) & ODP & QLP & VOC & QP & TDT & CPR & CMI & ECPH & EDP & EQP & ESR \\
\hline Confidence & $100 \%$ & $100 \%$ & $90 \%$ & $75 \%$ & $100 \%$ & $100 \%$ & $75 \%$ & $100 \%$ & $60 \%$ & $40 \%$ & $40 \%$ & $40 \%$ \\
\hline
\end{tabular}

\section{Scenario 3 (C3): "High-confidence rating"}

Finally, the third scenario considered (Scenario 3, or Sc3 for short) is a high-confidence rating scenario, and we use $100 \%$ confidence on all criteria of past, future and present data.

\subsection{Results analysis}

Observing the results obtained for the 30 problems it is possible to verify that five different groups of results were reached, henceforth denoted Case 1, ... Case 5, achieved from the three different scenarios (Sc1, Sc2, and $\mathrm{Sc} 3$ ), as follows:

Table 4. Five different groups of results mapped to scenarios.

\begin{tabular}{cc} 
Case & Exp \\
\hline 1 & $\mathrm{Sc} 1, \mathrm{Sc} 2$ and $\mathrm{Sc} 3$ \\
\hline 2 & $\mathrm{Sc} 1$ and $\mathrm{Sc} 2$ and $\neq \mathrm{Sc} 3$ \\
\hline 3 & $\mathrm{Sc} 2$ and $\mathrm{Sc} 3$ and $\neq \mathrm{Sc} 1$ \\
\hline 4 & $\mathrm{Sc} 3$ and $\neq \mathrm{Sc} 1$ and $\mathrm{Sc} 2$ \\
\hline 5 & $\mathrm{Sc} 1, \mathrm{Sc} 3$ and $\neq \mathrm{Sc} 2$
\end{tabular}

This means, for instance, that when Case 1 occurs the results obtained through the application of scenarios 1,2 and $3(\mathrm{Sc} 1, \mathrm{Sc} 2$ and $\mathrm{Sc} 3)$ are the same as the result of the illustrative example; and in Case 2, the results obtained through scenarios 1 and 2 (Sc1 and $\mathrm{Sc} 2$ ) are the same but scenario 3 reached a different solution, and so on. Figure 12 presents the number of occurrences of these five scenarios that were obtained for the thirty problems considered.

As we can see in Figure 12, Case $1(\operatorname{Exp}=\mathrm{Sc} 1, \mathrm{Sc} 2$ and $\mathrm{Sc} 3$ ) occurred the most (i.e., in 17 of the total 30 problems analysed), which means that for around $56.7 \%$ of the problems the three cases (Case 1, Case 2 and Case 3) did reach exactly the same solution of the illustrative case. Case $2(\operatorname{Exp}=\mathrm{Sc} 1$ and $\mathrm{Sc} 2$ and $\neq \mathrm{Sc} 3)$ occurred just 2 times (6.7\%); Case 3 (Exp $=\mathrm{Sc} 2$ and $\mathrm{Sc} 3$ and $\neq \mathrm{Sc} 1)$ occurred 3 times $(10 \%)$, Case $4(\operatorname{Exp}=\mathrm{Sc} 3$ and $\neq \mathrm{Sc} 1$ and $\mathrm{Sc} 2)$ occurred 7 times $(23.3 \%)$; and Case 5 occurred just 1 time $(3.3 \%)$.

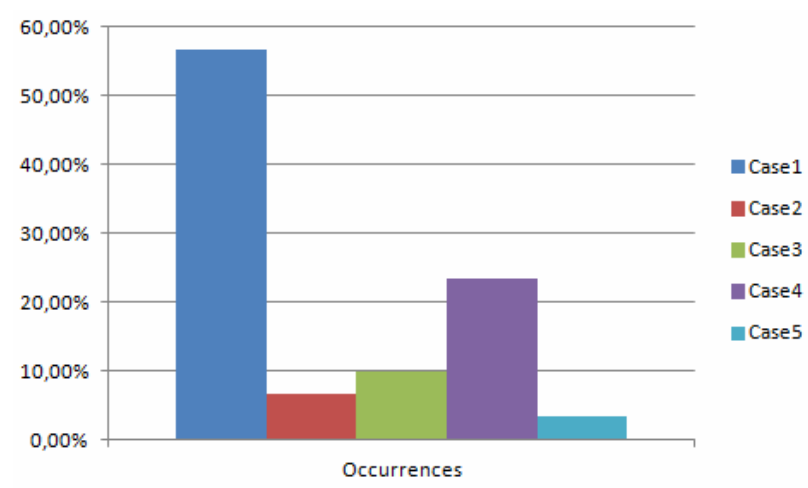

Figure 12: Frequencies of the five cases.

These results highlight the expected behaviour of our DMCDM model, as the higher is the confidence level about the data (regarding past, future and present information) the closer the results are to the ones illustrated in the example. 
Moreover, the results obtained show that Scenario 1 found the optimal solution for 20 problems $(66.6 \%)$ instances, while Scenario 2 found the optimal solution for 22 problems $(73.3 \%)$, and Scenario 3 found the optimal solution for 28 problems (93.3\%). Further, through another statistical analysis performed using SPSS software on the results obtained it was also possible to conclude with statistical evidence, and with $95 \%$ of confidence, through the application of the ChiSquare test that the three Scenarios (1,2 and 3) analysed did perform similarly to the case study, i.e. we may consider the non-existence of difference between each scenario and the original result evaluations, as shown in Tables 5, 6 and 7, for Scenarios 1, 2 and 3, respectively.

For evaluating the significance of the obtained results through the Chi-Square test, we used the following two hypotheses:

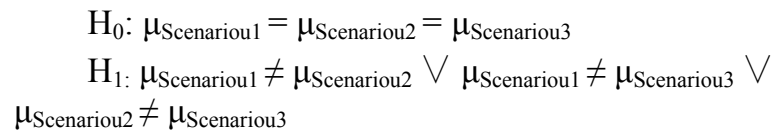

Table 5. Chi-Square Tests (Sc1).

\begin{tabular}{|c|r|r|r|}
\hline & Value & df & Asymp. Sig. (2-sided) \\
\hline Pearson Chi-Square & $10,063^{\mathrm{a}}$ & 12 &, 610 \\
Likelihood Ratio & 10,878 & 12 & \\
Linear-by-Linear Association &, 063 & 1 &, 539 \\
N of Valid Cases & 120 & &, 802 \\
\hline
\end{tabular}

Table 6. Chi-Square Tests (Sc2).

\begin{tabular}{|c|r|r|r|}
\hline & Value & df & Asymp. Sig. (2-sided $)$ \\
\hline Pearson Chi-Square & $3,960^{\mathrm{a}}$ & 4 &, 411 \\
Likelihood Ratio & 4,064 & 4 & \\
Linear-by-Linear Association &, 032 & 1 &, 397 \\
N of Valid Cases & 60 & & \\
\hline
\end{tabular}

Table 7. Chi-Square Tests (Sc3).

\begin{tabular}{|c|r|r|r|}
\hline & Value & df & Asymp. Sig. (2-sided) \\
\hline Pearson Chi-Square & $2,672 \mathrm{a}$ & 4 &, 614 \\
Likelihood Ratio & 2,726 & 4 & \\
Linear-by-Linear Association &, 279 & 1 &, 605 \\
N of Valid Cases & 60 & &, 597 \\
\hline
\end{tabular}

Therefore, hypothesis H0 was accepted with $95 \%$ of confidence level. Consequently, the results obtained (expressed through Tables 5 to 7) allow concluding that there is no significant difference between the results obtained through the three alternative scenarios considered, when compared with the original results. Moreover, we may conclude that scenario 3 reached the better results followed by scenario 2 , while scenario 1 performed worse -as expected - since it was the scenario attributing the lowest confidence level to past, forecast and present rating values.

\section{CONCLUSION}

In this paper we discussed a dynamic multicriteria decision making approach, which uses data fusion and a filtering uncertainty process to enable more informed strategic decisions about partnerships or suppliers selection under uncertain environments. The proposed approach combines a dynamic spatial-temporal model $[4,5,13]$ with a data fusion method [4] and, also, a semantic normalization process based on a simple fuzzification process [6].

The proposed approach is dynamic, allowing the evaluation process to include historical information, present status and forecasting information under uncertain contexts. Companies will be able to adjust how the evaluation process is performed depending on the three types of available information they have about suppliers and their interactions in a spatial-temporal imprecise context. Furthermore, historical information may include one or more past periods, depending on the quantity of available information that is available and the whole process can be done periodically, when strategic decisions about suppliers and partnerships have to be made. In addition the approach enables handling uncertainty in data, which abounds on this type of contexts, particularly for current and estimated data.

In order to validate the performance and robustness of the proposed approach a sensitivity analysis was presented based on three different scenarios - each with different confidence levels for criteria data quality- over a set of thirty problems considered for businesses' selection. In order to obtain significance of the results, different analyses were performed, including a statistical analysis through the Chi-Square test.

In summary we can say the approach is also highly customizable and flexible, allowing buyer companies to define different criteria for past, present and future evaluations. Further, the capability to deal with business problems in uncertain environments provides a good solution for decision support scenarios where data quality may be compromised because it accepts specific confidence levels depending on the information quality. Additionally, each criterion weight is dependent of its classification level of satisfaction, thus it ensures more discrimination between alternatives (e.g. alternatives with badly satisfied criterion will have its score decreased) and less impact in the final raking of badly satisfied criteria.

\section{ACKNOWLEDGMENT}

The authors wish to acknowledge the support of the Fundação para a Ciência e Tecnologia (FCT), Portugal, through the grant: "Projeto Estratégico - PEst2015-2020, reference: UID/CEC/00319/2013.

\section{REFERENCES}

[1] Dubois, A., Araujo, L., (2007). Case research in purchasing and supply management: opportunities and challenges. Journal of Purchasing and Supply Management, 13, 170-181.

[2] Sniijders, C. and Vos, B. Eds. (2007) Special issue on Methods, Journal of Purchasing and Supply Management 13(3).

[3] Van Weele, A. J. and van Raaij, E. M. (2014), The Future of Purchasing and Supply Management Research: About Relevance and Rigor. Journal of Supply Chain Management, 50: 56-72.

[4] Ribeiro, R.A., Falcão, A., Mora, A., \& Fonseca, J. M. (2013). FIF: A fuzzy information fusion algorithm based 
on multi-criteria decision making. Knowledge-Based Systems.

[5] Jassbi, J. J., Ribeiro, R. A., and Varela, L- R. (2014). Dynamic MCDM with Future Knowledge for Supplier Selection, Journal of Decision Systems http://dx.doi.org/10.1080/12460125.2014.886850.

[6] Varela, L. R. and Ribeiro, R. A. (2003). Evaluation of simulated annealing to solve fuzzy optimization problems. Journal of Intelligent and Fuzzy Systems, Vol. 14, No 2: 59-72. URL: http://dblp.unitrier.de/db/journals/jifs/jifs14.html\#VarelaR03.

[7] Figueira, J., Greco, S., and Ehrgott, M. (eds.) (2005) Multiple Criteria Decision Analysis: State of the Art Surveys. Kluwer Academic Publishers, Dordrecht.

[8] Tzeng, G.H. Huang, J.-J. (2011). Multiple Attribute Decision Making: Methods and Applications, CRC Press, 2011.

[9] Xu, Z. (2008). On multi-period multi-attribute decision making. Knowledge-Based Systems.

[10] Zulueta, Y. Martínez-Moreno J., Bello Pérez R., Martínez L. A (2014), discrete Time variable Index for Supporting Dynamic Multi-criteria Decision Making. International Journal of Uncertainty, Fuzziness and Knowledge-Based Systems 22(1): 1-22.Beskok, A., Karniadakis, G.E. and Trimmer, W.: Rarefaction and compressibility effects in gas microflows, Trans. ASME J. Fluids Eng, Vol. 118, No. 3, pp. 448-456, 1996.

[11] Da Costa P. C.G. and Buede D. M. (2000), Dynamic Decision Making: A Comparison of Approaches Journal of Multi-Criteria Decision Analysis. 9: 243-262.

[12] Yu P-L-and Chen Y-C (2010). Dynamic multiple criteria decision making in changeable spaces: from habitual domains to innovation dynamics. Annals of Operation Research DOI 10.1007/s10479-010-0750-x.

[13] Campanella, G., Pereira, A., Ribeiro, R.A., and Varela, L.R. (2012). Collaborative Dynamic Decision Making: a Case Study from B2B Supplier Selection. In Decision Support Systems - Collaborative Models and Approaches in Real Environments. Hernández, J.E., Zarate, P., Dargam, F. Delibašic, B., Liu, S. and Ribeiro, R. (Eds.), Lecture Notes in Business Information Processing (LNBIP), Springer Berlin Heidelberg, Volume 121: 88102.

[14] Pais, T. C. Ribeiro, R. A. Simões, L. F. (2010). Uncertainty in dynamically changing input data. In: Computational Intelligence in Complex Decision Systems. DaRuan (Ed), Atlantis Computational Intelligent Systems, Vol. 2, Chapter 2, World Scientific ISBN: 9789078677277, DOI: 10.2991/978-94-91216-2992.

[15] Roy, B. (1996). Multicriteria Methodology for Decision Aiding. Kluwer Academic Publishers.

[16] Dutta, S. (1997). Strategies for Implementing Knowledge-Based Systems. IEEE Transactions on Engineering Management, Vol. 44, 1, p. 79-90.

[17] De Boer, L., Wegen, L., \& Telgen J. (1998). Outranking methods in support of supplier selection, European.

[18] Zadeh, L. A. (1965). Fuzzy Sets. Information and Control.8:338-353, 1965.

[19] Ribeiro, R.A. (1996). Fuzzy multiple attribute decision making: a review and new preference elicitation techniques. Fuzzy sets and systems, 78, 155-181.

[20] Amid, A., Ghodsypour, S.H., \& O’Brien, C. (2006). Fuzzy Multiobjective Linear Model for Supplier
Selection in a Supply Chain. International Journal of Production Economics 104 (2): 394- 407.

[21] Wang, T.Y., \& Y.H. Yang. (2009). A fuzzy model for supplier selection in quantity discount environments. Expert Systems with Applications, 36: 12179-12187.

[22] Elahi, B., S.M. Seyed-Hosseini, A. Makui (2011). A Fuzzy Compromise Programming Solution for Supplier Selection in Quantity Discounts Situation. International Journal of Industrial Engineering \& Production Research, 22(2): 107-114.

[23] Pang, B., and Bai, S. (2011). An integrated fuzzy synthetic evaluation approach for supplier selection based on analytic network process. Journal of Intelligent Manufacturing, 24(1), 163-174.

[24] Ozkok, B.A., \& F. Tiryaki (2011). A compensatory fuzzy approach to multi-objective linear supplier selection problem with multiple-item. Expert Systems with Applications, 38: 11363-11368.

[25] Bowersox, D., \& Closs, D. (1996). Logistical Management - The Integrated Supply Chain Process. 730 pages. McGraw-Hill, ISBN 0-07-114070-0.

[26] Ross, T. J., (2014). Fyzzy Logic with Engineering Applications, John Wiley \& Sons Ltd, England.

[27] Pereira, R.A.M., and Ribeiro, R.A. (2003). Aggregation with generalized mixture operators using weighting functions, Fuzzy Sets Syst., 137(1), 43-58.

[28] Varela, L. R. and Ribeiro, R. A. (2014), "Distributed Manufacturing Scheduling Based on a Dynamic MultiCriteria Decision Model, Recent Developments and New Directions in Soft Computing," Zadeh L.A., Abbasov A. M., Yager R. R., Shahbazova, Sh. N., Reformat M. Z. (Eds.), Studies in Fuzziness and Soft Computing, Vol. 317 , pp. 618-623, Springer, Germany.

\section{ВРЕМЕНСКО-ПРОСТОРНИ ПРИСТУП ИЗБОРУ ПОСЛОВНОГ ПАРТНЕРСТВА У НЕИЗВЕСНИМ ОКРУЖЕЫИМА}

\section{А. Араиш-Каштро, М.Л.Р. Варела, Р.А. Рибеиро, Г.Д. Путник}

Мале и средње компаније све више су изложене изазовима у покушају да примене глобализоване стратегије пословања. Модели савременог пословања треба да понесу одговорност у окружењима која се мењају у времену и простору и где недостатак поверења и неизвестност података представљају реалност. Даље, мале и средње компаније имају све више потешкоћа да укључе у своју структуру све потребне компетентности; због тога, да би биле успешне, треба да се ослањају на поуздано партнерство у пословању и снабдевању. У овом раду се разматра временско-просторни приступ доношењу одлука у циљу успешног овладавања недостатком поверења и непрецизношћу актуелних података и/или њиховим предвиђањем. Избор пословног партнерства илуструје студија случаја која показује подобност приступа, што допуњава статистичка анализа различитих нивоа неизвестности у циљу процене робустности приступа у неизвесним окружењима. 